\title{
Analysis of Corruption Eradication Commitment in Judge's Verdict on-Court District in Law Zone in South Sulawesi Province
}

\author{
Firman Umar* \\ Departemen of Pancasila and Civic \\ Education \\ Faculty of Social Science \\ State University of Makassar \\ Makassar, Indonesia \\ firman.umar@unm.ac.id
}

\author{
Muhammad Akbal \\ Departemen of Pancasila and Civic \\ Education \\ Faculty of Social Science \\ Universitas Negeri Makassar \\ Makassar, Indonesia \\ m.akbal@unm.ac.id
}

\author{
Mustari \\ Departemen of Pancasila and Civic \\ Education \\ Faculty of Social Science \\ Universitas Negeri Makassar \\ Makassar, Indonesia \\ mustari@unm.ac.id
}

\begin{abstract}
This research aims to find out and to analyze whether the judge of district court dropped the verdict according to the public prosecutors' demands? This study was empirical law research. Techniques of collecting data used were interviews and documentation. Analysis data was done qualitatively namely the data collected both primary and secondary data which are compiled and it analyzed qualitatively by the researchers through interpreting, elaborating, describing, and arranging the data systematically based on the research objective. From the result of this study, the researchers found that during in 2013 until May, 6th, 2019, there was several judge decision which suits with prosecutors' demands, namely for the imprisonment cases was 48 cases, for the criminal fine was 433 cases, and the punishment for compensating the state losses was 217 cases. Nevertheless, there is a tendency for court judgment of corruption is lighter than the public prosecutor.
\end{abstract}

Keywords: eradication corruption commitment, Judge verdict of Makassar District Court.

\section{INTRODUCTION}

This study focuses on analyzing corruption eradication commitment in judge verdict of Court district in Makassar City by using two legal perspectives and sociological point of view (empirical/reality).

Corruption is any act that is against the law intending to enrich (profitable) themselves or others or a corporation, abusing the authority, chance or the tool that exist to him because of a position that could harm the state's finances or the country's economy.

As for, the criminal sanctions for corruption are regulated in Law Number 20 of 2001 juncto/in connection with Law Number 31 of 1999 about Eradication of Corruption [1], such as criminal threats that are primary in nature, Article 2 paragraph (1) confirms that "... against the law doing an action to enrich themselves or other people or a corporation that can harm the finances of the country or the country's economy can be jailed with life time sentence for the shortest is 4 (four) years and the maximum is 20 (twenty) years and at least Rp. 200,000,000.00 fine (two hundred million rupiah) and maximum is $\mathrm{Rp} 1,000,000,000.00$ fine (one billion rupiah). Article 2 paragraph (2) confirms, in case of corruption criminal act as referred to in Section (1) it should be carried out under certain condition, the death penalty may be dropped.
Meanwhile, a criminal threat that is a "subsider/as substitute" which means that penalty of confinement as a substitute for a penalty if the person convicted does not pay it is arranged in Article 3, it set that, "each person with the purpose of self-benefit or any other person or corporation, misuse the authority, chance or tools that it exists with him/her because of the position that could harm the country's finances or the country's economy, he/she can be jailed with life time sentence or imprisonment for the shortest is 1 (one) year and the longest is 20 (twenty) years, and/or at least Rp. $50,000,000.00$ fine (fifty million rupiahs) and maximum is Rp. 1,000,000,000.00 fine (one billion rupiah) ". Article 4 governs that, "the return of compensating for state financial losses or country's economy does not make the perpetrators will not be punished, as referred to in Article 2 and 3".

In criminal matters context, there are three possibilities of court judgments [2]. First, the defendant will be free because what the public prosecutor's indictment has not proved legally and it convinces. Second, the defendant will be decided to be free from all lawsuit, it means that the deed that the public prosecutor's indictment has been proved and it convince but the deed is not a criminal act. Usually, in the decision from all lawsuits, there are reasons for criminal erased, whether it is justified or forgiving reasons. Third, the defendant was convicted if the deed that was accused by the public prosecutor proved legally and it convinces [3].

As for, the judges are given attribution authority by Article 24 (1) Paragraph (1) of the Constitution of the Republic of Indonesia of 1945[3], where the judges have independency to hold justice to enforce the law and justice. Further, Article 28 paragraph (1) of the Law of the Republic of Indonesia Number 48 of 2009 on Judicial Power is regulated that: " the judges must dig, follow and understand the laws value and justice that live in a society". From the explanation of that article mentioned: "this provision is intended to make judge's decision is same as the law and the sense of justice in society".

The judges as a law enforcement officer are work to examine, prosecute, and decide the cases that proposed to them. Reksodiputro (in Syamsu, 2018)[4] states that "prosecute action is the most important issue and it is the centre of the criminal justice system". It is said that because at this stage it was decided whether the defendant was found guilty and therefore he/she convicted or innocent, because if that, he/she free from all lawsuits. Thus, a court's judgment 
is an important history for the reflection of justice, including a court's judgment which is a criminal law and condemnation. Thus, through the role of judges, corruption can be controlled, financial and economic countries can be saved, and finally, it makes a great contribution to thedevelopment that brings the welfare of society. The judges are the central position in enforcing the law and justice [5].

The novelty of this research is to analyse the commitment to corruption crimes eradication in Judge verdict of Court district in Makassar City from 2013 until May, 6th, 2019.

The problem of this research: corruption crimes in Indonesia is still one of the causes degenerate the nation's economic system. This is because corruption in Indonesia occurs systematically and extends, so it is not only detrimental the state's financial condition, but also it has violated the social rights and economic of the society broadly, the data in the trend report in the case of corruption in 2018, issued by Indonesian Corruption Watch that is the average value of the country's losses, criminal corruption per case in 2018, namely Rp 7.8 billion, which is it different with two the previous years, namely in 2016 where the country's losses Rp 4.2 billion per case. While in 2017, it was 6.7 billion. It means that from the trend, the state losses because of corruption crime was quite increased per case1.

Based on the data from the Indonesia Corruption Watch (2017) [6], it can be seen in the following table below:

Table 1 . The average imprisonment in each court level

\begin{tabular}{|c|l|l|}
\hline No & \multicolumn{1}{|c|}{ Court name } & \multicolumn{1}{|c|}{$\begin{array}{c}\text { Average } \\
\text { Criminal Prison }\end{array}$} \\
\hline 1. & $\begin{array}{l}\text { Corruption Crime Court In } \\
\text { The District Court }\end{array}$ & two years one month \\
\hline 2. & $\begin{array}{l}\text { Corruption Crime Court In } \\
\text { The High Court }\end{array}$ & two years two months \\
\hline 3. & Supreme Court & Five years \\
\hline \multicolumn{2}{|c|}{ Average } & Two years two months \\
\hline
\end{tabular}

(Source: the trend verdict or corruption case on the first semester in 2017, published by ICW on May, 3th, 2018)

The table shows that the average verdict dropped in 2017 was only two years, two months in jail or it classified as a mild category. This can be influenced by the use of the Article that is an indictment by the prosecutor namely, Article 2 paragraph (1) and Article 3 the law of a criminal act of corruption, where the minimum criminal contained in both Articles is 4 (four) years and 1 (one) year. It can be seen in the following table as follows:

This research aims to find and to analyze whether the Judges of Court District drop the verdict according to the public prosecutor's demands as a form of eradication commitment of corruption efforts?

\section{METHOD}

This research was an empirical legal research study that is intended to study whether Judges of District Court dropped the verdict based on the prosecutor's demands by looking applicable law and regulation (law in the book) and what happened in the reality in society (law in action).

The legal approach is used to investigate the legislation of the Republic of Indonesia Law number 20 of 2001 juncto/in connection with Law number 31 of 1999 on corruption eradication; Law of the Republic of Indonesia
Number 48 of 2009 on judicial Power and Law of the Republic of Indonesia Number 8 of 1981 about Criminal Procedure Code and the Law of Republic of Indonesia number 16 of 2004 about the Prosecutor [7].

Meanwhile, empirical approaches used to investigate the analysis of the commitment to the corruption eradication in the judges' verdict at Makassar Court City from 2013 to May, 6th, 2019.

The data sources used in this study were taken from primary and secondary data. The primary data was obtained directly from interviewees/first informant related to the focus of this research problem through interviews with the judge of the criminal act of corruption in Makassar City. Meanwhile, secondary data was obtained through exploring and collecting from various sources to complete the primary data, such as searching the data related to the number of matters handled by the District Court in Makassar City on the official website (http://sipp.pn-makassar.go.id/), and other documents such as books, research results or journals that is relevant to this study.

Research instruments: Interview guidelines, with some questions that have been formulated by the researchers to be given to interviewees/informant so that the researchers got the answers to the problem of this research. During the interview process, the researchers observed, noted, and recorded all the answers given by interviewees/informant.

Techniques of analyzing data used in solving the problems: the data obtained from the field analyzed by the researchers according to the characteristics of the corresponding data [8]. For the data that is the numbers, the researchers created the data in the form of tables then it explained descriptively. Analysis data was done qualitatively namely the data collected both primary and secondary data are compiled and analyzed qualitatively by interpreting, elaborating, describing and arranging it systematically based on the research objective [9] [10].

\section{RESULT AND DISCUSSION}

The results of this study found that since 2013 until May, 6th, 2019, there were several court judgement based on the prosecutors' demands, namely for imprisonment was 48 cases, for the criminal fine was 433 cases, and the punishment for the country's losses was 217 cases. Nevertheless, there is a tendency of the court judgment to criminal acts of corruption are lighter than the public prosecutor's demands. It has been confirmed through the data as follows:

Table 2. The Comparison of prosecutors and judges' verdict in 2013

\begin{tabular}{|c|c|c|c|c|c|c|c|}
\hline \multirow[b]{2}{*}{ No. } & \multirow[b]{2}{*}{ Categories } & \multicolumn{2}{|c|}{ Imprisonment } & \multicolumn{2}{|c|}{ Fines } & \multicolumn{2}{|c|}{ Substitute refunds } \\
\hline & & $\begin{array}{c}\text { Absolute } \\
\text { Frequency }\end{array}$ & $\begin{array}{l}\text { Relative } \\
\text { Frequency }\end{array}$ & $\begin{array}{l}\text { Absolute } \\
\text { Frequenc }\end{array}$ & $\begin{array}{l}\text { Relative } \\
\text { Frequency }\end{array}$ & $\begin{array}{c}\text { Absolute } \\
\text { Frequency }\end{array}$ & $\begin{array}{c}\text { Relative } \\
\text { Frequency }\end{array}$ \\
\hline 1 & Mayor & 8 & $6.96 \%$ & 3 & $2.61 \%$ & 2 & $3.63 \%$ \\
\hline 2 & Same & 10 & $8.70 \%$ & 76 & $66.09 \%$ & 31 & $56,3 \%$ \\
\hline 3 & Minor & 83 & $72.17 \%$ & 24 & $20.87 \%$ & 7 & $12,72 \%$ \\
\hline 4 & Free & 2 & $1.74 \%$ & 8 & $6.96 \%$ & 15 & $27,27 \%$ \\
\hline 5 & $\begin{array}{l}\text { The data is } \\
\text { not complete }\end{array}$ & 12 & $10.43 \%$ & 4 & $3.48 \%$ & - & - \\
\hline & TOTAL & 115 & $100 \%$ & 115 & $100 \%$ & 55 & $100 \%$ \\
\hline
\end{tabular}


Table 3. The Comparison of prosecutors and judges' verdict in 2014

\begin{tabular}{|c|c|c|c|c|c|c|c|}
\hline \multirow[b]{2}{*}{ No. } & \multirow[b]{2}{*}{ Categories } & \multicolumn{2}{|c|}{ Imprisonment } & \multicolumn{2}{|c|}{ Fines } & \multicolumn{2}{|c|}{ Substitute refunds } \\
\hline & & $\begin{array}{l}\text { Absolute } \\
\text { Frequency }\end{array}$ & $\begin{array}{l}\text { Relative } \\
\text { Frequency }\end{array}$ & $\begin{array}{l}\text { Absolute } \\
\text { Frequency }\end{array}$ & $\begin{array}{l}\text { Relative } \\
\text { Frequency }\end{array}$ & $\begin{array}{l}\text { Absolute } \\
\text { Frequency }\end{array}$ & $\begin{array}{l}\text { Relative } \\
\text { Frequen } \\
\text { cy }\end{array}$ \\
\hline 1 & Mayor & 3 & $3,09 \%$ & 4 & $4,12 \%$ & 2 & $4,34 \%$ \\
\hline 2 & Same & 3 & $3,09 \%$ & 67 & $69,07 \%$ & 35 & $78,26 \%$ \\
\hline 3 & Minor & 77 & $79,38 \%$ & 12 & $12,37 \%$ & 5 & $10,86 \%$ \\
\hline 4 & Free & 6 & $6,19 \%$ & 9 & $9,28 \%$ & 4 & $8,69 \%$ \\
\hline 5 & $\begin{array}{l}\text { The data is not } \\
\text { complete }\end{array}$ & 8 & $8,25 \%$ & 5 & $5,15 \%$ & - & - \\
\hline & TOTAL & 97 & $100 \%$ & 97 & $100 \%$ & 46 & 100 \\
\hline
\end{tabular}

Table 4. The Comparison of prosecutors and judges' verdict in 2015

\begin{tabular}{|c|l|c|c|c|c|c|c|}
\hline \multirow{2}{*}{ NO. } & \multirow{2}{*}{ Categories } & \multicolumn{2}{|c|}{ Imprisonment } & \multicolumn{2}{c|}{ Fines } & \multicolumn{2}{c|}{ Substitute refunds } \\
\cline { 2 - 8 } & $\begin{array}{l}\text { Absolute } \\
\text { Frequency }\end{array}$ & $\begin{array}{l}\text { Relative } \\
\text { Frequency }\end{array}$ & $\begin{array}{l}\text { Absolute } \\
\text { Frequency }\end{array}$ & $\begin{array}{l}\text { Relative } \\
\text { Frequency }\end{array}$ & $\begin{array}{l}\text { Absolute } \\
\text { Frequency }\end{array}$ & $\begin{array}{l}\text { Relative } \\
\text { Frequency }\end{array}$ \\
\hline 1 & Mayor & 6 & $6,32 \%$ & 4 & $4,21 \%$ & 7 & $14,89 \%$ \\
\hline 2 & Same & 4 & $4,21 \%$ & 75 & $78,95 \%$ & 27 & $57,44 \%$ \\
\hline 3 & Minor & 73 & $76,84 \%$ & 4 & $4,21 \%$ & 3 & $6,38 \%$ \\
\hline 4 & Free & 8 & $8,42 \%$ & 8 & $8,42 \%$ & 9 & $19,14 \%$ \\
\hline 5 & $\begin{array}{l}\text { The data is } \\
\text { not complete }\end{array}$ & 4 & $4,21 \%$ & 4 & $4,21 \%$ & 1 & $2,12 \%$ \\
\hline \multicolumn{2}{|c|}{ TOTAL } & $\mathbf{9 5}$ & $\mathbf{1 0 0 \%}$ & $\mathbf{9 5}$ & $\mathbf{1 0 0 \%}$ & $\mathbf{4 7}$ & $\mathbf{1 0 0 \%}$ \\
\hline
\end{tabular}

Table 5. The Comparison of prosecutors and judges' verdict in 2016

\begin{tabular}{|c|l|c|c|c|c|c|c|}
\hline \multirow{2}{*}{ NO. } & \multirow{2}{*}{ Categories } & \multicolumn{2}{|c|}{ Imprisonment } & \multicolumn{2}{c|}{ Fines } & \multicolumn{2}{c|}{ Substitute refunds } \\
\cline { 3 - 8 } & & $\begin{array}{l}\text { Absolute } \\
\text { Frequency }\end{array}$ & $\begin{array}{l}\text { Relative } \\
\text { Frequency }\end{array}$ & $\begin{array}{l}\text { Absolute } \\
\text { Frequency }\end{array}$ & $\begin{array}{l}\text { Relative } \\
\text { Frequency }\end{array}$ & $\begin{array}{l}\text { Absolute } \\
\text { Frequency }\end{array}$ & $\begin{array}{c}\text { Relative } \\
\text { Frequency }\end{array}$ \\
\hline 1 & Mayor & 7 & $5,69 \%$ & 10 & $7,87 \%$ & 2 & $3,64 \%$ \\
\hline 2 & Same & 9 & $7,32 \%$ & 13 & $10,24 \%$ & 3 & $67,27 \%$ \\
\hline 3 & Minor & 94 & $76,42 \%$ & 91 & $71,65 \%$ & 9 & $16,36 \%$ \\
\hline 4 & Free & 11 & $8,94 \%$ & 12 & $9,45 \%$ & 7 & $12,73 \%$ \\
\hline 5 & $\begin{array}{l}\text { The data is } \\
\text { not complete }\end{array}$ & 2 & $1,63 \%$ & 1 & $0,79 \%$ & - & \\
\hline \multicolumn{2}{|c|}{ TOTAL } & $\mathbf{1 2 3}$ & $\mathbf{1 0 0} \%$ & $\mathbf{1 2 7}$ & $\mathbf{1 0 0 \%}$ & $\mathbf{5}$ & $100 \%$ \\
\hline
\end{tabular}

Table 6. The Comparison of prosecutors and judges' verdict in 2017

\begin{tabular}{|c|l|c|c|c|c|c|c|}
\hline \multirow{2}{*}{ NO. } & \multirow{2}{*}{ Categories } & \multicolumn{2}{|c|}{ Imprisonment } & \multicolumn{2}{c|}{ Fines } & \multicolumn{2}{c|}{ Substifute refinds } \\
\cline { 3 - 9 } & $\begin{array}{l}\text { Absolute } \\
\text { Frequency }\end{array}$ & $\begin{array}{l}\text { Relative } \\
\text { Frequency }\end{array}$ & $\begin{array}{c}\text { Absolute } \\
\text { Frequency }\end{array}$ & $\begin{array}{l}\text { Relative } \\
\text { Frequency }\end{array}$ & $\begin{array}{l}\text { Absolute } \\
\text { Frequency }\end{array}$ & $\begin{array}{c}\text { Relative } \\
\text { Frequency }\end{array}$ \\
\hline 1 & Mayor & 2 & $1,52 \%$ & 1 & $0,76 \%$ & 2 & $2,90 \%$ \\
\hline 2 & Same & 11 & $8,33 \%$ & 108 & $81,82 \%$ & 37 & $53,62 \%$ \\
\hline 3 & Minor & 107 & $81,06 \%$ & 13 & $9,85 \%$ & 18 & $26,09 \%$ \\
\hline 4 & Free & 5 & $3,79 \%$ & 5 & $3,79 \%$ & 12 & $17,39 \%$ \\
\hline 5 & $\begin{array}{l}\text { The data is not } \\
\text { complete }\end{array}$ & 6 & $4,55 \%$ & 5 & $3,79 \%$ & - & - \\
\hline 6 & Fall & 1 & $0,76 \%$ & - & & - & - \\
\hline \multicolumn{2}{|c|}{ TOTAL } & $\mathbf{1 3 2}$ & $\mathbf{1 0 0 \%}$ & $\mathbf{1 3 2}$ & $\mathbf{1 0 0 \%}$ & $\mathbf{6 9}$ & $100 \%$ \\
\hline
\end{tabular}

Table 7. The Comparison of prosecutors and judges' verdict in 2018

\begin{tabular}{|c|c|c|c|c|c|c|c|}
\hline \multirow[b]{2}{*}{ No. } & \multirow[b]{2}{*}{ Categories } & \multicolumn{2}{|c|}{ Imprisonment } & \multicolumn{2}{|c|}{ Fines } & \multicolumn{2}{|c|}{ Substitute refunds } \\
\hline & & $\begin{array}{l}\text { Absolute } \\
\text { Frequency }\end{array}$ & $\begin{array}{l}\text { Relative } \\
\text { Frequency }\end{array}$ & $\begin{array}{l}\text { Absolute } \\
\text { Frequency }\end{array}$ & $\begin{array}{l}\text { Relative } \\
\text { Frequency }\end{array}$ & $\begin{array}{l}\text { Absolute } \\
\text { Frequency }\end{array}$ & $\begin{array}{c}\text { Relative } \\
\text { Frequency }\end{array}$ \\
\hline 1 & Mayor & 5 & $5,95 \%$ & - & - & 2 & $3,92 \%$ \\
\hline 2 & Same & 9 & $10,71 \%$ & 65 & $78,31 \%$ & 40 & $78,43 \%$ \\
\hline 3 & Minor & 65 & $77,38 \%$ & 12 & $14,46 \%$ & 1 & $1,96 \%$ \\
\hline 4 & Free & 2 & $2,38 \%$ & 3 & $3,61 \%$ & 5 & $9,80 \%$ \\
\hline 5 & $\begin{array}{l}\text { The data is not } \\
\text { complete }\end{array}$ & 2 & $2,38 \%$ & 2 & $2,41 \%$ & 2 & $3,92 \%$ \\
\hline 6 & $\begin{array}{l}\text { The data is not } \\
\text { acceptable }\end{array}$ & 1 & $1,19 \%$ & 1 & $1,20 \%$ & 1 & $1,96 \%$ \\
\hline & TOTAL & 84 & $100 \%$ & 83 & $100 \%$ & 51 & $100 \%$ \\
\hline
\end{tabular}

Table 8. The Comparison of prosecutors and judges' verdict on May, 6th, 2019

\begin{tabular}{|c|c|c|c|c|c|c|c|}
\hline \multirow[b]{2}{*}{ NO. } & \multirow[b]{2}{*}{ Categories } & \multicolumn{2}{|c|}{ Imprisonment } & \multicolumn{2}{|c|}{ Fines } & \multicolumn{2}{|c|}{ Substitute refunds } \\
\hline & & $\begin{array}{l}\text { Absolute } \\
\text { Frequency }\end{array}$ & $\begin{array}{l}\text { Relative } \\
\text { Frequency }\end{array}$ & $\begin{array}{l}\text { Absolute } \\
\text { Frequency }\end{array}$ & $\begin{array}{l}\begin{array}{l}\text { Relative } \\
\text { Frequency }\end{array} \\
\end{array}$ & $\begin{array}{l}\text { Absolute } \\
\text { Frequency }\end{array}$ & $\begin{array}{c}\text { Relative } \\
\text { Frequency }\end{array}$ \\
\hline 1 & Mayor & 2 & $6,25 \%$ & 1 & $3,13 \%$ & 3 & $15,79 \%$ \\
\hline 2 & Same & - & - & 29 & $90,63 \%$ & 10 & $52,63 \%$ \\
\hline 3 & Minor & 29 & $90,63 \%$ & 1 & $3,13 \%$ & 2 & $10,53 \%$ \\
\hline 4 & Free & - & - & - & - & 3 & $15,79 \%$ \\
\hline 5 & $\begin{array}{l}\text { The data is not } \\
\text { complete }\end{array}$ & 1 & $3,13 \%$ & 1 & $3,13 \%$ & 1 & $5,26 \%$ \\
\hline & TOTAL & 32 & $100 \%$ & 32 & $100 \%$ & 19 & $100 \%$ \\
\hline
\end{tabular}

In the practice of corruption criminal trials, the difference punishment is the usual things and it does not violate the law, because there are three reasons: first, every case has its characteristics; second, in Criminal Code Procedure, it does not found Article that requires the judge to give punishment based on the prosecutor's demands; Third, the duty of judges is not merely applying and enforcing the law (bouche de la loi), but also apply and enforce the justice (fiat justitia) (Act No. 48 of 2009 on Judicial Power), so that the judges have independence in determining the punishment based on the consideration of the law and their conscience [11].

Normatively, judicial power as an independent power to administer the judiciary to enforce the law and justice (Article 24 of the Constitution of the Republic of Indonesia and Law Number 49 of 2008 on judicial power). It explicitly and firmly set in Article 4 paragraph (1) of Law Number 49 of 2008 on Judicial Power that "the judiciary is done for justice based on the almighty God". While Article 4 paragraph (3) affirm prohibits other parties of judicial power to get involved in judicial affairs; and Article 5 paragraph (1) which set that "judges and constitutional judges must dig, follow, and understand the legal values and sense of justice that exist in society.

It is not easy to realize the justice value and the legal certainty in every court's judgment, because in the legal system in Indonesia is known the mechanism of "dissenting opinion", however open access towards the results of the process become the court's judgment (close system), moreover, concerning the professionalism of judges in discovering the law (rechtsvinding), and the moral integrity that commits prioritizes a fair decision [12].

One of the weaknesses in Criminal Code and Criminal Code Procedure that we have is there is no criminal guideline can be used by judges to give punishment [13]. In general, the parameters of a court judgment, including a criminal court, besides it based on legal certainty, it also must rely on fairness and benefit. Legal certainty becomes crucial so that perpetrators do not feel like a victim from the criminal justice system. While, justice is the fundamental value that must be covered in the court judgment, while the benefit is a practical value that must benefit the perpetrators of criminal crimes suffered.

Regarding the benefit of the criminal case court verdict, Bentham (2006) ${ }^{[9]}$ states that besides the retaliation, the important features of criminal justice must be beneficial. There are three benefits of imprisonment, namely: (1) It will be very beneficial if it can improve self-improvement in the perpetrators of crime; (2) It should eliminate the ability to commit crimes; and (3) It must compensate to the party that is harmed. 
Further, Bentham stated that the punishment does not have any justification value if it is merely imposed to add more suffering or its harm to society. Based on Bentham's idea, it can be understood that this involved the victims and the perpetrators in the decision-making so that the sanctions imposed on the perpetrators also notice to their life in the future. In the context of a corruption crime court judgment in Indonesia, it only focused on the legal certainty which notices to the provisions of the law [14] [15]. Whether the decision is beneficial to cause a deterrent effect or it is fair for the perpetrators, or it is not optimal yet. A court judgement must be based on legitimate evidence with judge's beliefs and it is not based on public opinion.

\section{CONCLUSION}

During in 2013 until May, 6th, 2019, there were several judge's verdicts which are based the prosecutors' demand, namely for imprisonment was 48 cases, for the criminal fine was 433 cases, and the punishment to change the country's losses was 217 cases. However, there is a tendency to judge's verdict for the criminal act of corruption is lighter than the public prosecutors' demand.

The implication of this research is to eradicate corruption crimes, then law supremacy should be enforced through a repressive effort that is judge's decision for the criminal act of corruption need to be maximized, and also public prosecutors' demand also need to be maximized against the defendant, both imprisonment and criminal fine which is based on the Articles that indicted to the defendant, so that it can be educated them (giving deterrent effect) as well as preventing corruption, thus it does not happen again.

\section{ACKNOWLEDGMENT}

This article is the result of PNBP FIS UNM research with contract number SP-DIPA-042.01.2.400964/2019 Lembaga Penelitian dan Pengabdian Masyarakat, Universitas Negeri Makassar.

\section{REFERENCES}

[1] T. Lyston, "Restoration for State's Financial Loss as a Countermeasure against Corruption in Indonesia," Int. J. Soc. Sci. Perspect., vol. 2, no. 2, pp. 161-164, 2018.

[2] J. T. Ulmer and B. Johnson, "Sentencing in context: A multilevel analysis," Criminology, vol. 42, no. 1, pp. 137-178, 2004.

[3] E. O. S. Hiariej, "Menyoal Putusan Pengadilan Tindak Pidana Korupsi," Masal. Huk., vol. 42, no. 1, pp. 5562, 2013.

[4] M. A. Syamsu and M. H. SH, Penjatuhan Pidana \& Dua Prinsip Dasar Hukum Pidana. Prenada Media, 2018.

[5] E. Saks, "Representing miscegenation law," Interracialism Black-white intermarriage Am. Hist. Lit. law, pp. 61-81, 2000.

[6] A. Caesar, L. Easter, and E. Yuntho, "Catatan Pemantauan Perkara Korupsi yang Divonis oleh Pengadilan Selama Januari-Juni 2016.” 2016.

[7] H. A. Ellion, "The Basis of Judges' Authority in Adjudicating Criminal Cases in the Perspective of Judicial Power in Indonesia," JL Pol'y Glob., vol. 73, p. $177,2018$.
[8] A. J. Onwuegbuzie, W. B. Dickinson, N. L. Leech, and A. G. Zoran, "A qualitative framework for collecting and analyzing data in focus group research," Int. J. Qual. methods, vol. 8, no. 3, pp. 1-21, 2009.

[9] W. N. Suter, "Qualitative data, analysis, and design," Introd. to Educ. Res. A Crit. Think. approach, vol. 2, pp. 342-386, 2012.

[10] U. Kuckartz, Qualitative text analysis: A guide to methods, practice and using software. Sage, 2014.

[11] A. W. Alschuler, "The trial judge's role in plea bargaining, Part I," Columbia Law Rev., vol. 76, no. 7, pp. 1059-1154, 1976.

[12] U. de Vries, "Law \& lounge: an experiment on student self-organization and critique as skeptical reflexivity," in Academic Learning in Law, Edward Elgar Publishing, 2016.

[13] C. Berdejó and N. Yuchtman, "Crime, punishment, and politics: an analysis of political cycles in criminal sentencing," Rev. Econ. Stat., vol. 95, no. 3, pp. 741756, 2013.

[14] J. Braithwaite, "Restorative justice: Assessing optimistic and pessimistic accounts," Crime and justice, vol. 25, pp. 1-127, 1999.

[15] H. Packer, The limits of the criminal sanction. Stanford University Press, 1968. 